\title{
“¿A QUÉ PELEAR SI LOS DE MADRID NO QUIEREN?” UNA VERSIÓN CRIOLLA DE LA GUERRA DEL 98 EN PUERTO RICO
}

\author{
POR \\ MARÍA DE LOS ANGELES CASTRO ARROYO \\ Universidad de Puerto Rico, Río Piedras
}

A través del estudio del diario de guerra que Ángel Rivero Méndez comenzó a escribir en 1898, se analiza la posición mantenida por el pueblo puertorriqueño ante el 98. En él mismo se destaca que fue la disposición del propio país la que facilitó el triunfo de los norteamericanos. Una postura que era consecuencia del pasado colonial y que desembocó en el cansancio de la población ante las medidas tomadas por su antigua metrópoli, que no revertían en su desarrollo y mejora. Asimismo, se plantean los sentimientos de confusión e incertidumbre experimentados, al mismo tiempo, por la población una vez concluida la guerra.

DEL DIARIO A LA CRÓNICA/DE LA CRÓNICA A LA HISTORIA

«La verdad es lo que es, y nada más.»

Desde el mismo día en que asumió el mando del castillo de San Cristóbal y sus baterías, el 1 de marzo de 1898, Ángel Rivero Méndez abrió un diario de la guerra, en el que se propuso anotar las incidencias de los eventos prestos a ocurrir que pudieran interesar a futuros lectores. Cerró sus páginas el 23 de octubre de ese año cuando registró la salida del vapor Montevideo a bordo del cual regresaba a España el general Ricardo Ortega, segundo cabo y gobernador militar de la plaza de San Juan, con las últimas tropas pendientes de repatriarse. Para entonces, ya tenía decidido escribir un libro bajo el título de Crónica de la guerra hispanoamericana que, según él, le 
fue sugerido por el general Ortega ${ }^{1}$. Con la óptica de un oficial confinado a un puesto importante y subordinado a jefes controvertibles, Rivero trasladó a su diario lo que observó, palpó y vivió durante esos inquietantes meses, como si quisiera perpetuar la memoria de todo cuanto aconteció en los aciagos días ${ }^{2}$.

La génesis del libro está en el diario y es indudable que desde el primer momento Rivero tuvo la intención de que fuera así. Lo que resulta menos comprensible es la razón por la cual pospuso durante veintitrés años su redacción. Aduce el propio autor que lo aplazó para complacer a Ortega ${ }^{3}$. Mas, ¿qué motivo pudo tener éste para desear ese retraso? Quizás procuró evitar roces mayores, al regresar a la Península, con otras autoridades insulares de las cuales disintió durante el conflicto y sobre las que sabía Rivero habría de manifestarse. ¿Llegó Ortega a leer el diario? Es probable, dado que permaneció en San Cristóbal durante la guerra, trabó amistad con Rivero y luego le proporcionó documentos, pero no conoció el libro pues murió en 1917 , cinco años antes de que saliera a la luz pública ${ }^{4}$. La cita de Henry Cabot Lodge que encabeza el Prólogo, ofrece otra pista. El entonces senador del Congreso norteamericano planteó que la historia de esta guerra no podría escribirse hasta muchos años más tarde para dar tiempo a que se recogiera el material necesario y «obtener la perspectiva y proporción que solamente la distancia puede dar.. ${ }^{5}$ Cabe pensar que esas mismas inquietudes asaltaran a Rivero y le llevaran a posponer su obra hasta tanto pudiera allegar la información que le permitiera corroborar y enriquecer muchas de las primeras impresiones plasmadas en el diario, $\mathrm{y}$, sobre todo, para dejar que el paso del tiempo templara sus «juveniles arrestos» ${ }^{6}$.

\footnotetext{
1 Ángel Rivero, Crónica de la guerra hispanoamericana en Puerto Rico. San Juan, Instituto de Cultura Puertorriqueña, 1972, pp. 1, 73. La primera edición terminó de imprimirse en diciembre de 1922.

${ }^{2}$ El diario se reproduce en el Apéndice núm. 1, pp. 533-74.

${ }^{3}$ RIVERO, [1], p. 73.

${ }^{4}$ Ibidem, p. 485. A juzgar por el Prólogo, fechado en marzo-abril de 1921, y la inclusión de testimonios fechados en 1921 y 1922, el libro debió concluirse poco antes de imprimirse a fines del último año. Por consiguiente, puede asumirse que Ortega tampoco leyó el manuscrito, al menos en su totalidad.

5 Henry CABOT LODGE, The War With Spain. s.e., 1899.

6 RIVERO, [1], p. viii.
} 
Es evidente, además, la intención de Rivero de refutar versiones escritas por militares españoles a raíz del conflicto en las cuales emitieron juicios y apreciaciones que Rivero rechaza?

Al cerrarse el doloroso período de la evacuación de la isla, se escribió en España, por jefes y oficiales que en ella sirvieron, y que aún sentían las nostalgias de sus jugosas nóminas, libros, folletos y artículos en la Prensa, y en los cuales se medía con igual rasero a hijos del país y a los voluntarios; todos traidores, todos cobardes. Ninguno de los que manejaron la pluma en la Madre Patria, con mayor gentileza que sus espadas en la ínsula, habló de las torpezas y arbitrariedades de «los de arriba», causantes, si no de la totalidad, de la mayor parte del desastre. Se escribió mucho; se calumnió libremente, injustamente ${ }^{8}$.

De modo que a la intención prístina de guardar memoria de lo ocurrido, sumó un compromiso: el de contar «la verdad», el de corregir errores y hacer las rectificaciones que consideró necesarias para hacer justicia y fijar las debidas responsabilidades por los resultados de la guerra. A la larga, fue éste el propósito que predominó y dio al libro un cierto carácter polémico y contestatario.

Rivero se inserta dentro de la corriente historiográfica del positivismo. Está convencido de que sólo existe una verdad única, comprobable mediante datos irrefutables: «La verdad es lo que es y nada más.» Desviarse de ese principio básico de buscar y encontrar «la verdad» absoluta sería mentir y «mentir sería desvirtuar hechos para satisfacer conveniencias o amistades personales», algo inadmisible para él ${ }^{9}$. Como está consciente de ser partícipe de los hechos que narra, reclama que su libro no es una historia sino una crónica y

7 Entre otros, el del comandante de ingenieros y ayudante de campo del general Macías, Julio Cervera Baviera, La defensa militar de Puerto Rico. San Juan de Puerto Rico, Imprenta de la Capitanía General, 1898. Sobre éste opina que «es un conjunto de inexactitudes, desde el principio al final. No tiene un solo dato cierto ni una sola apreciación bien fundada, siendo una loa entonada en honor al último capitán general de Puerto Rico, y una diatriba, sin precedentes, contra el país puertorriqueño y contra los Voluntarios». Según Rivero, la intención del autor era mantener en secreto el folleto, de unas 35 páginas, y distribuirlo en España a la llegada de Macías para influenciar a favor de éste la opinión del pueblo español. El opúsculo aparece reproducido en Cayetano COLL y TOSTE, ed, Boletín Histórico de Puerto Rico. VI, p. 722. También refuta escritos del teniente coronel Francisco LARREA, aparecidos en la revista Estudios Militares y en su libro El desastre nacional y los vicios de nuestras instituciones.

8 RIVERO, [1], p.452. Cf. también p. 473.

9 Ibidem, p. viii. 
afirma haber escrito sólo lo que vio y escuchó y lo que pudo constatar por «documentos auténticos o declaraciones probadas de testigos presenciales, de honorabilidad intachable.» ${ }^{10} \mathrm{Sin}$ embargo, la envergadura de la investigación que prosiguió al diario, su afán por esclarecer hechos controvertidos y reivindicar honras injustamente injuriadas, las explicaciones tras la narrativa y el análisis particular que hace de la marcha de los acontecimientos y de las decisiones que los afectaron, hacen que el libro sea tanto crónica como historia de la guerra. Puesto que el autor parte de su propia experiencia, tiene también reflejos autobiográficos.

En el empeño de llegar a «la verdad», hay un fuerte reclamo de imparcialidad. Rivero se propuso hacer creíble su historia. Por eso no agotó esfuerzos para buscar información que apoyara, ampliara y complementara sus propias vivencias. Visitó archivos militares y gubernamentales en Madrid y Washington, escribió y entrevistó a múltiples participantes, interrogándoles sobre eventos específicos en los que habían intervenido, siempre buscando las fuentes más cercanas a los hechos. Corroboró y confrontó las versiones españolas con las norteamericanas, tomó partido cuando encontró discrepancias y, no vaciló en presentar versiones contrapuestas dejando al lector juzgar por sí mismo. A lo largo del texto intercaló largas citas tomadas de cartas, informes, entrevistas y otros documentos que pudieran verificar sus planteamientos. Inconforme con eso, anejó 35 apéndices documentales. Además, para ilustrar y animar los hechos narrados, procuró la colaboración de Rafael Colorado, fotógrafo peninsular y teniente coronel de la guerrilla montada voluntaria que vio acción en Yauco. Juntos recorrieron la ruta de los soldados de ambos bandos para dejar un sólido complemento gráfico de la palabra escrita. El testimonio de Colorado sobre lo sucedido en Yauco también se incluyó en el libro. Es decir, buscó las pruebas que pudieran atestiguar la objetividad y la veracidad de su versión sobre la forma como llegó, evolucionó y concluyó la guerra en Puerto Rico.

La Crónica es esencialmente un «libro de guerra, de re militare», tal como quiso su autor ${ }^{11}$. Incluso está dedicado al Cuerpo de Artillería del Ejército Español y en el grabado que enmarca la página del título, en la primera edición de 1922, Rivero aparece identificado

\footnotetext{
${ }^{10}$ Ibidem, p. viii.

11 Ibidem, p. viii.
} 
con su rango de capitán de artillería. Es auténtico su entusiasmo al contar las peripecias de la guerra (como cuando describe el bombardeo de la ciudad de San Juan, el 12 de mayo) y las partes que más desarrolla del libro y expone con mayor minuciosidad son las relativas a los preparativos previos, las estructuras defensivas, los pertrechos y armamentos con que se enfrentaban los dos ejércitos, las estrategias seguidas por los jefes de ambos bandos y las operaciones de la campaña en sí. Tampoco se le escapa el contexto más amplio de la guerra en relación con Cuba, sobre todo, la destrucción de la Armada del almirante Cervera en la bahía de Santiago. Creía que las maniobras contra esta ciudad, antes y después de su caída, ejercieron una gran influencia sobre la campaña de la Antilla Menor ${ }^{12}$.

En un libro que busca perpetuar y reivindicar memorias castrenses, la acción individual, el carácter y el comportamiento humanos, ocupan un lugar central. Las operaciones de campo, el diseño de estrategias y las decisiones adoptadas están dirigidas por personas específicas. No se consideran procesos más complejos como, por ejemplo, la carrera expansionista que habían iniciado los Estados Unidos en el siglo XIX, ni la decadencia de España con sus razones. Rivero muestra especial interés en destacar hazañas heroicas y actos de abnegación, caballerosidad y gallardía, pero también apunta las que, según él, fueron flaquezas humanas de los que antepusieron, en coyunturas difíciles, la conveniencia al honor. Se extiende en cavilaciones y juicios éticos sobre la conducta humana, muy matizados por su propio código de honor. Hasta cierto punto, la Crónica trata el enfrentamiento entre héroes y villanos de diverso peso específico. Como sabe que su libro, y, desde luego, sus juicios, podían mortificar a algunos coetáneos, pide que no lo culpen escudándose tras su «labor de cronista» relator de hechos ${ }^{13}$.

Contra los propósitos expresos del autor, el libro excede lo puramente militar. Aunque prevalece este interés primordial, Rivero extiende su mirada más allá y compila infinidad de noticias directas e indirectas sobre la vida civil. En especial, logra recrear muy bien el clima imperante durante el período pre-bélico y los distintos momentos de la guerra. Con humor e ironía, recoge anécdotas e inci-

\footnotetext{
12 Ibidem, p. 178.

13 Ibidem, p. viii. Para ejemplo del tono recriminatorio y moralizante que adopta en determinados momentos cf. p. 42.
} 
dencias que van desde asuntos triviales y jocosos, como el del farol que confundieron con un espía transmisor de señales, hasta tragicomedias de la cotidianidad, como la del éxodo de los habitantes de San Juan. Mas tampoco es la Crónica un popurrí donde se mezcla todo por igual. El autor es selectivo con lo que incluye y excluye del texto. Alega que deja de publicar muchas cosas «íntimas» que tiene registradas porque su libro no es «un padrón de escándalo ni una gacetilla para solaz de curiosos o desocupados.» ${ }^{14}$ Es decir, desea mantenerse ajeno a la frivolidad, a todo lo que pueda restarle gravedad al importante asunto que lo ocupa. Es un libro escrito por un alto oficial que asume muy en serio su respetabilidad.

\section{EL CAPITÁN CRONISTA}

«Un oficial no abandona el uniforme cuando hay probabilidades de guerra, disponga usted de mí.»

Ángel Rivero Méndez no era un militar cualquiera. Nacido en los campos del barrio Cacao de Carolina, hijo de padres canarios, estudió en San Juan, Toledo y Segovia, graduándose de ingeniero industrial con el grado de teniente de artillería. Fue secretario de la oficina principal del cuerpo de artillería y tuvo a su cargo durante tres años el archivo de la división. Entre 1896 y 1898 desempeñó sucesivamente las cátedras de Química-Física y Matemáticas en el Instituto Civil de Segunda Enseñanza ${ }^{15}$. Era miembro del Partido Incondicional Español y algunas referencias lo sitúan como colaborador ocasional de los periódicos conservadores La Integridad $\mathrm{Na}$ cional y La Balanza Mercantil, aunque es probable que sus artículos aparecieran sin firma para evadir la prohibición a los militares de intervenir en asuntos políticos ${ }^{16}$. Consta que sus aventuras periodís-

\footnotetext{
${ }^{14}$ Rivero, [1], p. viii.

15 Ibidem, Del archivo de la división extrajo la información que le permitió escribir el capítulo 30 del libro en el que hace una reseña histórica del servicio militar en Puerto Rico, pp. vii, 6-7, 90.

${ }^{16}$ Fue una intervención política, probablemente en la prensa, la que originó su arresto en el Morro, de donde lo sacó Macías con un indulto para que se hiciera cargo de San Cristóbal y sus baterías cuando la guerra se hizo inminente. p. I; Juan B. HUYKE, Triunfadores. San Juan de Puerto Rico, Negociado de Materiales, Imprenta y Transporte, 1926, 2
} 
ticas le llevaron a celebrar duelos con Mariano Abril, Enrique Hernández, José Gordils y Luis Rodríguez Cabrero entre los años 189596. Durante la última década del siglo fue frecuente que los periodistas se batieran a duelo para dirimir honras afectadas por artículos de prensa ${ }^{17}$. Estas incursiones de Rivero en el periodismo pueden percibirse en el libro en las inflexiones un tanto editorialistas con que comenta muchos de los hechos, sobre todo cuando critica errores de juicio, decisiones mal tomadas por las autoridades militares y otras situaciones alusivas a cuestiones de honor.

Como buen soldado formado en academias militares españolas de fines de la centuria decimonónica, Rivero tiene arraigado un profundo sentido del honor. Se rige por un severo código moral, prisma a través del cual juzga todas las acciones humanas, civiles y militares. Lo resume en la imagen de la línea recta que debe marcar el camino en la vida de todo hombre de bien.

Los dos puntos extremos, el que marca el nacer y el que señala la muerte, están unidos por una línea recta. Tal es el único camino que deben recorrer en la vida los que, siendo hombres de honor, luchan para alcanzar el engrandecimiento y libertades de su Patria ${ }^{18}$.

El honor es un protagonista importante en su historia de la guerra y los atributos del honor no visten uniforme de colores determinados. Por eso, expone con plena independencia de criterio su admiración por las dotes del enemigo y fustiga con igual libertad a los de su propio bando que fallaron en ejecutar lo que se esperaba de ellos.

\section{UNA GUERRA ENTRE CABALLEROS}

«Esta breve campaña de 1898 es un modelo de guerra culta, moderna y humanitaria.»

\footnotetext{
vols., I, pp. 185-92; Adolfo DE Hostos, Tesauro de datos históricos. Río Piedras, Editorial de la Universidad de Puerto Rico, 1994, 5 vols., IV, p. 909, Crónica, pp. 1-2, 561.

17 Antonio S. Pedreira, El periodismo en Puerto Rico en Obras de Antonio S. Pedreira, tomo II. San Juan de Puerto Rico, Instituto de Cultura Puertorriqueña, 1970, pp. 301-4; HosTOS, [16], p. 909.

18 RIVERO, [1], Cf., por ejemplo, la p. 42.
} 
Rivero es un militar criollo atrapado entre imperios y entre ejércitos. Está pillado entre la lealtad a España y Puerto Rico y el entusiasmo que le despiertan las maniobras militares y el comportamiento del ejército norteamericano. Ese sentimiento pendular, reflejado en el libro de diversas maneras, debió causar penosas tribulaciones al alma del cronista. El contraste entre los bandos en pugna es constante y los instrumentos de guerra no son las únicas armas con las que combaten. También rivalizaron en el campo del honor y la conducta militar.

Esta medición de fuerzas y un sentido de lealtad personal, muy vinculado a su código de honor, indujeron a Rivero al cometido autoimpuesto de rescatar el prestigio de algunos jefes y grupos de voluntarios, actores del lado español, cuyas conductas fueron puestas en entredicho por ciertas autoridades superiores que al final de la guerra quisieron arrimar la brasa a su sartén. Reivindicar el valor y el honor de esos soldados, sirve a la tesis subyacente del autor de que los defensores pudieron haber presentado al enemigo una cara diferente, una resistencia más honrosa. Era, además, lo único que el autor podía salvar para España y Puerto Rico después de la estrepitosa derrota.

Las oscilaciones del hombre cogido en un entre-siglos, que marcó para la isla el advenimiento acelerado a la modernidad bajo un nuevo régimen, quedaron registradas en el tono general del libro. El prólogo abre con un acento dramático, apesadumbrado, de pérdida. «La jornada gloriosa que comenzara el 19 de noviembre de 1493 ... tuvo su epílogo doloroso el 18 de octubre de 1898, a mitad de ese día, cuando en los castillos y palacios de San Juan flotó, con arrogancia de vencedor, el pabellón estrellado de la Unión Americana.» ${ }^{19}$ Sin embargo, Rivero se recupera enseguida, y aunque deja claro que amó y fue fiel a España, y en ocasiones asoman dejos de nostalgia, su hispanofilia es controlada, libre de sentimientos exaltados. Creo que dos factores principales, nacidos de la guerra, influenciaron su postura. Primero, Rivero terminó por anteponer su propio país, sobre todo ante la decepción que le causaron los juicios desenfocados y las decisiones desacertadas del gobiemo español en la

19 Ibidem, p. v. Además, cf. pp. 564-5 en las que confía a su diario las incidencias de su «noche triste» al enterarse del cese de las hostilidades y de la pérdida de Cuba y Puerto Rico.

R. I., $1997, \mathrm{n}^{\circ} 211$ 
Península y en Puerto Rico. El modo como se comportaron «los de arriba» durante y después de la guerra pudo llevarlo a sopesar algunas de sus posiciones políticas anteriores. Por el contrario, desarrolló una profunda admiración hacia el ejército invasor y sus jefes principales, en particular el Generalísimo Nelson A. Miles. A lo largo del libro alaba abiertamente la política de «guerra sabia», la cultura militar que exhibieron los caudillos norteamericanos antes, durante y después de concluidas las hostilidades, resaltadas aún más al contraponerlas con la peninsular.

¿Qué cualidades fueron las que captaron la atención de Rivero y lo llevaron a pensar que se peleó una guerra «civilizada»? Las resume en el Prólogo y luego las repite una y otra vez cuando comenta hechos concretos.

...se respetaron las costumbres, leyes y religión de los nativos; se mantuvo en toda su fuerza el brazo de la autoridad civil, a pesar del estado de guerra; no se utilizó el abusivo sistema de requisas, sino que todo era pagado, incluso el terreno donde levantaban sus tiendas, a precio de oro. Su proclama, sabiamente urdida y hábilmente circulada, despertó en todo el país anhelos de libertad y progreso que encendieron los corazones de los más tímidos campesinos. Lugo Viña, Carbonell, Mateo Fajardo, Nadal, Luzumaris y otros pocos, penetraban a un tiempo mismo en los pueblos y en el corazón de sus habitantes como precursores de un ejército que batía marcha de honor ante las damas, besaba y repartía candies a los niños. Soldados que se batían y hacían jornadas de treinta millas bajo un sol de fuego del mes de julio, y luego, en Hormigueros, de rodillas ante el padre Antonio, rezaban a la misma virgen de la Monserrate, tan venerada por todo el oeste de la Isla.

Esta política de la guerra; esta cultura militar; el hombre tras el cañon - the man behind the gun-y los numerosos sacos de oro acuñado que trajeran Miles, Brooke y Wilson, allanaron su camino, limpiándolo de obstáculos ${ }^{20}$.

Debemos recordar que Rivero plasma en el libro sus impresiones sobre los sucesos de la guerra y el cambio de mando. Se atiene a la historia del aquí y el ahora. No opina sobre los resultados inmediatos y a más largo plazo. Aun cuando eventos posteriores contradijeron varias de las percepciones forjadas al calor de una guerra muy desigual, rehusa inmiscuirse en los debates políticos que apasiona-

${ }^{20}$ RIVERo, [1], p. vii. Énfasis en el original. 
ron las dos décadas transcurridas entre el diario y la Crónica. De modo que fueron acciones específicas de las operaciones militares y los trámites y ceremonias de cambio de mando los que perfilaron sus imágenes del ejército invasor. En la guerra, jefes y soldados se condujeron con caballerosidad e hidalguía. Nos describe cómo el capitán Vernou enterró y puso flores sobre la tumba de un soldado español muerto en la escaramuza de Yauco y luego exigió respeto a su memoria ${ }^{21}$; deja constancia de la carta que el capitán Harry Alvan Hall envió a la viuda del capitán Rafael Martínez de Illescas, muerto heroicamente en el combate de Coamo, expresándole admiración por el valor de su esposo ${ }^{22}$, cuenta sobre la disposición de las tropas invasoras para compartir sus raciones con los prisioneros ${ }^{23}$ y brindar a los heridos auxilios médicos ${ }^{24}$; y aunque menciona algunos desórdenes ocurridos, se extiende más en el control ejercido por las autoridades norteamericanas para evitarlos o detenerlos de inmediato ${ }^{25}$. Los muestra en la victoria gentiles y magnánimos con el vencido. Cuando se organiza en los pueblos el relevo de autoridades, son las tropas triunfantes las que procuran impedir que la población agravie a las que marchan en retirada, tal cual sucedió en Arecibo ${ }^{26}$. La alta jerarquía muestra igual nobleza cuando recibe la plaza de San Juan: permite a los propios soldados españoles arriar sus banderas en la tarde del 17 de octubre de modo que, al día siguiente, se izaron las banderas norteamericanas sobre astas que estaban desnudas. $\mathrm{Y}$ al pasar el trasatlántico Montevideo con las últimas tropas a bordo y las banderas españolas dobladas en una caja de cedro, las baterías de San Cristóbal, bajo las órdenes del capitán Reed, le saludaron con veintiún cañonazos ${ }^{27}$.

${ }^{21}$ Rivero, [1], p. vii, 203-4. Rivero rectifica que se le llame batalla de Yauco, pues lo que hicieron las tropas españolas fue tantear el enemigo para calcular su número e intenciones y entretenerlo hasta la llegada de refuerzos esperados que nunca aparecieron. Lo que llegó fue la orden de Macías para la retirada. p.202.

22 Ibidem, p. 249.

23 Ibidem, p. 336.

24 Ibidem, p. 331.

25 Ibidem, pp. 217, 221, 337, 572-3.

26 Ibidem, pp.394-5. Además, el comandante Darling, «por un impulso de militar caballerosidad», prometió no izar la bandera norteamericana hasta que el tren con las tropas evacuadas hubiese partido, lo que hizo cumplir.

${ }^{27}$ Ibidem, pp.419-20. 
Son igualmente interesantes algunas de las opiniones que Rivero reproduce sobre la mirada que nos echaron los norteamericanos.

Todos los americanos comenzamos a estudiar español y todos los puertorriqueños el inglés...

Las mujeres en Puerto Rico, o son muy lindas o son muy feas; no hay término medio. Los hombres no se embriagan ni maltratan a sus esposas; no se ocupan de negocios a la hora de comer ni a la hora de dormir; no profieren juramentos y otras palabras profanas y demuestran, en resumen, más interés por un soneto que por el precio de un barril de tocino.

Para hombres y mujeres, en Puerto Rico, la vida es una rosa, un cigarrillo, un cantar, una risa, un beso y un... mañana....28

Este juicio le sirve para reforzar su tesis de la afabilidad del soldado enemigo, sobre todo, porque no le contrapone otro de carácter peyorativo. Al margen de la intención de Rivero - y de todo lo que tiene de romántica e irreal- esta semblanza es un indicio de que no todos los norteamericanos participantes del conflicto tuvieron la opinión prejuiciada que se impuso en los círculos judiciales y gubernamentales de la esfera federal. El autor, al evadir entrar en polémicas posteriores a la guerra, limita el alcance de las palabras transcritas.

Para Rivero, la condición de guerra «culta» se debió, sobre todo, a Miles, quien convencido de que nunca hubo una causa justa porque la voladura del Maine ocurrió por reacciones químicas internas, «llevó a cabo una guerra... nada intensa... durante la cual evitó, en lo posible, toda innecesaria efusión de sangre...» ${ }^{29}$ Afirma, además, en el Prólogo, que la cortesía de los oficiales y soldados norteamericanos — que en el caso de Vernou «recordaba hazañas quijotescas de

${ }^{28}$ Rivero, [1], p 337. Reproduce del libro de Karl STEPHEN, From Yauco to Las Marías. Stephen fue un sargento de la brigada de Schwan. Para la época en que Rivero escribió el libro era un opulento banquero de Boston. Cuenta Rivero que tan pronto los americanos desembarcaron, empezaron a aparecer rótulos en inglés y se despertó un gran interés en aprender la lengua de los invasores. Ya en agosto circulaba un «vocabulario» titulado «Idioma inglés en siete lecciones» y periódicos en ese idioma. Rivero relata varias anécdotas sobre el asunto, algunas cargadas de ironía, como la que sigue, recogida en su diario, el 25 de agosto. «Me dicen que en muchos comercios pertenecientes a españoles en la ciudad de Mayagüez, han sido colocados unos cartelones que dicen: Don't enter you in here because it is a worst Spaniard... Tal vez aquellos españoles no sean buenos; pero el inglés de los cartelones es mucho peor.» p. 567. Enfasis en el original.

${ }^{29}$ Ibidem, pp. 12, 461. 
la andante caballería, muy del gusto de los puertorriqueños descendientes de aquellos caballeros andantes conquistadores de las Indias»- y la «política de guerra culta, moderna y civilizada» que sostuvieron, allanó el camino e inclinó la balanza del lado de Washington ${ }^{30}$.

En resumen, el convencimiento de Miles de que las causas del conflicto fueron injustificadas, sumado a su política de guerra, en la que eran prominentes los rasgos de amabilidad y consideración hacia el contrario, favorecieron, según Rivero, el triunfo de los norteamericanos. Este planteamiento sugiere que la situación pudo haber sido diferente de haber mediado otras circunstancias y nos lleva a inquirir respecto al ambiente previo a la guerra, sobre las condiciones y actitudes imperantes antes de que ocurriera la invasión. ¿Estaban los puertorriqueños predispuestos a recibir a los norteamericanos de la manera festiva como lo hicieron? ¿Qué trasluce la Crónica?

\section{«UNA FIEBRE DE GUERRA LO INVADE TODO»}

«Hombres, mujeres y hasta niños ofrecieron su vida, su oro y el trabajo de sus brazos. No faltó un solo pueblo; todos formaron guerrillas voluntarias, secciones de macheteros y auxiliares...»

«Como un solo hombre en pie de guerra» describe nuestro cronista el clima que prevalecía en Puerto Rico desde que se rompieron hostilidades $^{31}$. Recrea un ambiente de expectación y optimismo, enmarcado por declaraciones de fidelidad y lealtad a la metrópoli. Con entusiasmo patriótico, diferentes sectores de la población puertorriqueña apoyaron a España y se dispusieron a combatir. Da cuenta pormenorizada de los preparativos que se hicieron, de las medidas previsoras que se tomaron dentro de las limitaciones existentes y de la gran cantidad de rumores que circulaban, unos falsos, otros de medias verdades, algunos discordantes de carácter pesimista y los muy positivos. Según él, nadie en el país deseó la invasión norteamericana, salvo algunos «contados intelectuales y los bullangueros

\footnotetext{
30 Rivero, [1], p. vii. En la p. 422 vuelve a traer la imagen de los soldados españoles como herederos de Ponce de León, fundadores de la civilización que enriquecimos y conservamos y de la que nos sentimos orgullosos.

31 Ibidem, pp. 40-1.
} 
de cada pueblo». Cada quien puso de su parte. Las autoridades peninsulares e insulares del recién inaugurado gabinete autonómico y la prensa de todos los credos políticos divulgaron proclamas y arengas $^{32}$; médicos, practicantes, ancianos y «las más prominentes damas» se alistaron en la Cruz Roja ${ }^{33}$; muchos jóvenes se inscribieron en las guerrillas como voluntarios y macheteros auxiliares ${ }^{34}$; en la capital, otro grupo de jóvenes «de familias distinguidas» formó espontáneamente una escolta para defender al capitán general ${ }^{35}$; y se levantó una suscripción o colecta pública destinada a aumentar la partida de «Gastos de guerra» del presupuesto insular y atender otras urgencias propias del momento ${ }^{36}$. Para avivar los ánimos, se recordaba la heroica defensa frente a los ingleses en 1797 y hasta se publicó un artículo «probando» cómo corrían los yanquis delante de los machetes. La subvaloración del enemigo aumentaba la confianza y la disposición para enfrentarlo ${ }^{37}$.

Rivero insiste en demostrar que en el país existía un consenso previo a favor de España con el fin de refutar ideas vertidas posteriormente por algunos peninsulares que pretendieron culpar a los puertorriqueños de la derrota ${ }^{38}$. El capitán criollo invierte responsabilidades y yerros. Busca probar que, al declararse la guerra, en Puerto Rico se esperaba a los norteamericanos con espíritu combativo. Mas no puede tapar el cielo con la mano. Entonces, si la recepción que tuvieron los invasores fue muy distinta a la prevista, el cronista debe de explicar cuándo y por qué ocurrió la virazón. ¿A qué la atribuye? Desde su perspectiva de oficial puertorriqueño del ejército

\footnotetext{
34 Ibidem, pp. 49-50, 537. Da la cifra de más de mil para los primeros y cerca de 400 para los segundos. Pero estos números se contradicen y confunden en otras partes del libro. Por ejemplo, en la p. 47 establece que la isla contaba con 18.000 defensores de los cuales más de 8.000 eran veteranos. En la p. 201 mantiene en 8.000 la cifra de soldados regulares y fija en 6.000 los voluntarios.

35 Ibidem, pp. 49, 511. Esta escolta se disolvió el 17 de julio porque los jóvenes no pudieron sostener los gastos que acarreaba, p. 557.

36 Ibidem, pp 49-50, 470, 535, 537, 539, 545, 564, 558. El balance total de lo recolectado publicado por La Gaceta fue de 193.194,92 pesos. Cf. Apéndice 34, pp. 687-8.

37 Ibidem, p. 540. Se refiere al artículo de Guillermo Atiles García. Al rumor circulante sobre ese supuesto temor de los contrarios al arma blanca, Rivero comenta en su diario, con ironía, que por lo que pudiera ocurrir mandaría a afilar su sable.

38 Ibidem, CERVERA, [7].
} guerra.

32 RIVERO, [1], pp. 39, 40-2, 536-8, 540-1, 551

33 Ibidem, pp. 49-50. La institución comenzó labores en Puerto Rico con motivo de la 
español, Rivero siente la necesidad de urgar y exponer los motivos tras el cambio de actitud en gentes que hasta poco antes de la invasión estaban dispuestas a luchar y ofrecieron al gobernador sus vidas y fortunas para defender a España ${ }^{39}$.

\section{EL «PASEO TRIUNFAL» DE LOS NORTEAMERICANOS}

«La invasión de Miles revistió todos los caracteres de un paseo triunfal...»

Para Rivero, la razón principal que existe tras el colapso del entusiasmo inicial fue la actitud, la conducta asumida por las autoridades españolas, en la Península y en Puerto Rico, en diferentes momentos del conflicto. Según él, éste fue el elemento decisivo, el resorte principal que catapultó los eventos en dirección inversa. A fin de cuentas, el tipo de guerra «humanitaria» que pelearon los invasores recibió una ayuda sustancial de las deficiencias demostradas por los encargados de la defensa. Desavenencias entre los líderes, desidia e inacción en momentos claves, errores tácticos, toma de decisiones equivocadas, ausencia de estrategias y planes alternos, y la sordera ante sugerencias atinadas son algunas de las acusaciones principales que les hace.

Los tres [Macías, Vallarino y Ortega] vivieron en completo desacuerdo y en lucha constante, y contra los tres juntos operaba el coronel Camó desde su confortable despacho, anexo al Palacio del gobernador.

Tales delegaciones y tan lamentables desavenencias dieron fatales resultados en la preparación de la guerra y conducción de la misma. Nunca hubo previsión, planes ni concierto alguno ${ }^{40}$.

La responsabilidad de rehuir los combates y de no apostar tropas defensoras en los lugares apropiados en el momento indicado, Rivero la hace recaer mayormente en el jefe del Estado Mayor de Puerto Rico, coronel Juan Carnó, cuyos rasgos de carácter describe con muchos vicios y escasas virtudes. Sin embargo, la conducta del co-

39 RIVERO, [1], p. 470.

$40 \mathrm{Ibidem}$, p. 479. Para un ejemplo de discrepancia entre otros oficiales cf. pp. 306, 323. Vallarino era el comandante de Marina.

R. I., $1997, \mathrm{n}^{\circ} 211$ 
ronel parece cónsona con las directrices enviadas por el ministro de la Guerra. En un principio, se recibieron a través del cable arengas de guerra. Tras el desembarco por Guánica, el 25 de julio, el sentido cambió y se aconsejaba «economizar la vida de los soldados, pero dejando en todo caso a salvo el honor de las armas ${ }^{41}$. ¿Tenían Macías y Carnó instrucciones secretas de salvar el honor y evitar enfrentamientos que costaran innecesarias pérdidas de vida? ¿Sabían acaso que el protocolo de paz estaba cerca? ¿Fue desidia o sólo cumplieron órdenes de exponer a sus soldados lo menos posible, hasta donde la salvaguarda del honor lo permitiese? Rivero intuye algo de esto y recoge rumores circulantes al respecto ${ }^{42}$, pero es probable que si el mismo Ortega no tenía esta información, la percepción que prevaleciera en él fuera la que con mayor empeño deja entrever en su libro. Después de haber examinado la correspondencia habida entre los gobiernos de España y Puerto Rico, llega a la conclusión de que en ningún momento se impuso a Macías «aquel criterio suyo que dio al traste con el entusiasmo patriótico de militares y paisanos ${ }^{43}$.

Otra acusación que formula Rivero es la marcada desconfianza que demostró el Estado español hacia los puertorriqueños, lo que no permitió canalizar y obtener el mejor aprovechamiento de los recursos humanos disponibles y del entusiasmo de los primeros momentos de la guerra ${ }^{44}$. En su diario reprodujo un fragmento del artículo titulado «Hasta los gatos quieren zapatos», aparecido en el periódico La Correspondencia Militar, de Madrid, en el que se muestra cierto menosprecio por la capacidad de los nativos. Alude el escrito a una supuesta insurrección que se fraguaba en la Florida desde donde partirían las fuerzas invasoras y comenta, restándole importancia, que no había razones para asustarse porque bastaban cuatro soldados y un cabo para sofocar en la isla cualquier intentona ${ }^{45}$.

Opinión parecida debió tener Camó, a juzgar por la conducta que observó en relación con el Cuerpo de Voluntarios. Éste había sido una fuerza complementaria de orden público nacida después de la

${ }^{41}$ Rivero, [1], p. 471.

42 Ibidem, pp. 460, 473.

43 Ibidem, p. 470.

44 Ibidem, p. 50. Rivera culpa específicamente a Camó, «con su conducta poco discreta y nada acertada...»

45 Ibidem, p. 533. 
insurrección de Lares e integrada en su mayoría por peninsulares. Era, además, al decir de Rivero, «un partido político en armas; hasta mediados de mayo de 1898, sólo nutrieron sus filas hombres pertenecientes al llamado Partido Incondicionalmente Español de Puerto Rico $^{46}$. El propio Rivero había sido designado en 1896 abanderado de honor de sus 14 batallones $^{47}$. Durante los preparativos para la guerra, muchos puertorriqueños liberales y peninsulares que hasta entonces habían mirado con recelo a los Voluntarios, respondieron al llamado de Luis Muñoz Rivera y otras autoridades e ingresaron a las filas del Instituto. Hasta el momento de la invasión presentaron un bloque «unido y dispuesto a todos los sacrificios y contingencias del momento ${ }^{48}$. Costearon de su peculio personal uniformes, cabalgaduras y alimentos, encabezaron la suscripción popular para gastos de guerra, aportaron dinero para otras necesidades de campaña, como la de proveer materiales a la Cruz Roja, y rindieron un penoso servicio de guardacostas.

Con la clara intención de reivindicar el nombre de los Voluntarios, apaleado en escritos aparecidos en España después de firmado el Tratado de París, Rivero ofrece su explicación sobre lo ocurrido. El entusiasmo inicial de los Voluntarios se vino abajo, en primer lugar, ante la falta de resolución, las arbitrariedades y los desaciertos del coronel Camó. Ordenó que los Voluntarios que estaban sujetos al servicio militar activo, alrededor de 500, se incorporaran a las tropas regulares, lo que llevó a hombres prominentes a ingresar «sirviendo de estorbo» en los insuficientes cuarteles de la tropa veterana. Luego dispuso concentrarlos en las cabeceras de los departamentos en los que se dividía la isla, promoviendo que muchos abandonaran las armas para regresar a sus localidades con la intención de proteger sus familias y bienes. Las autoridades de San Juan los trataron con «marcado desprecio» e hicieron quemar en las plazas de muchos pueblos sus fusiles y correaje. En otras ocasiones, negaron a los comandantes militares de los distritos las armas y equipos que pedían para sus Voluntarios. Según se ordenaba el retiro de la tropa veterana y la Guardia Civil de las rutas de campaña, sólo quedaban en los pueblos los Voluntarios. Pero éstos constituían una milicia

\footnotetext{
46 RIVERO, [1], p 450.

47 Ibidem, p. 451.

48 Ibidem, p. 496, 451.
} 
ciudadana, auxiliar, «nunca el nervio en que debía apoyarse la defensa de una isla, dos veces bloqueada, por los buques americanos en sus costas y por fuerzas enemigas en el interior, y, además, por partidas de nativos que cruzaban en todas direcciones ${ }^{49}$.

Discurre que si hubo desaliento, temor y desbandada fue por falta de cimientos y sostén de parte de los llamados a ofrecerlos. Señala que los descontentos que abandonaron sus puestos no fueron los únicos en buscar su seguridad: «Hubo hasta un alto Tribunal de Justicia, que bien pudo celebrar vista pública en plena campiña.» Retrae conductas similares en Barcelona, Nueva York y Boston cuando gran parte de sus poblaciones se movieron hacia el interior al rumorearse las posibilidades de un ataque enemigo. Y termina con una reflexión sobre la conducta humana afirmando que el hombre es tan susceptible al entusiasmo como al temor y el desaliento. Puede arrojarse a la muerte tras un jefe valiente y osado o huir esquivando el peligro «si labios pusilánimes lanzan el grito de ¡sálvese el que pueda! $\gg^{50} \mathrm{Su}$ apreciación del problema y la voluntad de señalar los responsables principales y de dar a conocer el sentir del país no deja lugar a equívocos:

La conducción de la campaña fue un verdadero desastre; un cúmulo de errores, torpezas y equivocaciones, y en ningún momento se supo utilizar los valiosos medios de defensa con que contaba el estado militar del país. La frase «estamos abandonados» corría de boca en boca, y así, muchos, al arrinconar sus fusiles decían: - ¿A qué pelear si los de Madrid no quieren?51.

A las culpas repartidas entre los jefes del Estado Mayor de la isla, Rivero sumó otros factores también significativos. Los forma

49 Rivero, [1], pp. 449-52. Por fuerzas enemigas internas se refiere tanto a los espías e informantes norteamericanos como a los independentistas y anexionistas.

$50 \mathrm{Ibidem}$, p. 50. En la p. 455, Rivero indica que los mismos que antes calumniaron rectificaron luego sus juicios: «Años después, y al conocerse las vergüenzas de Manila y de Santiago de Cuba, aquellos apasionados escritores, que tan mal trataron antes a los Voluntarios de Puerto Rico, amainaron en sus críticas y rectificaron sus juicios. Y hasta alguno de ellos que, a raíz de la firma del Tratado de paz escribiera un desatentado artículo proponiendo que se retirasen a dichos voluntarios la condición de españoles [destacado en el original], anduvo, más tarde, por tierras de América, y tal vez por esta isla, meneando suavemente las cuerdas de su lira para que los -isiempre cándidos!- voluntarios del 1898 y sus hijos y sus amigos engordasen, con relucientes dólares, su escuálida bolsa.»

51 RIVERO, [1], p. 480. 
como circulaban noticias y rumores repercutían sobre los ánimos de la población. Los informes equivocados divulgados a principios de mayo sobre una supuesta victoria de la Armada española en Cavite (Filipinas) abonó la exaltación optimista de los primeros meses. Pero no tardó en llegar la dura verdad de que había sido destruida. A pesar de la censura y de la manipulación de noticias, a la de Cavite se unieron otras, indicadoras de que las cosas no pintaban como parecían al principio. El combate desigual entre el crucero auxiliar norteamericano Saint Paul, que bloqueaba el puerto, y el destróyer español Terror, y la catástrofe frente a las costas de Dorado del trasatlántico Antonio López, portador de pertrechos militares, ambos debidos a torpezas del comandante de Marina, general Vallarino, aflojaron la confianza que tenía el país en las fuerzas navales encargadas de protegerlo ${ }^{52}$. Esta terminó de perderse cuando se conoció lo ocurrido a la escuadra de Cervera en Santiago de Cuba. El 11 de julio, catorce días antes de la invasión de Puerto Rico, Rivero apuntó en su diario: «Esto ha causado un afecto abrumador; vamos perdiendo toda esperanza, no ya de victoria, sino de una paz ventajosa.» ${ }^{53}$

Aunque afirma que eran muy contados los puertorriqueños anexionistas, Rivero se muestra convencido de que la extensión de la guerra a Puerto Rico fue algo imprevisto, motivado por las gestiones de José Julio Henna y Roberto H. Todd ${ }^{54}$. Extraña que Rivero trate con cierta ingenuidad este asunto cuando dio cuenta de casos de espionaje como el del teniente $\mathrm{H}$. H. Whitney ${ }^{55}$ y el del periodista canadiense del New York Herald William Freeman Halstead, enviado a prisión por un Consejo de Guerra del que Rivero formó parte ${ }^{56}$. Además, él mismo explica que el objetivo principal del gobiemo español era defender a Puerto Rico, razón por la que envió a San Juan la escuadra del almirante Cervera ${ }^{57}$. Enterado Miles, propuso

\footnotetext{
52 RiVERO, [1], pp.149, 156, 163.

53 Ibidem, p.556.

54 Ibidem, pp. 17-9. Eran independentistas/anexionistas activos en la Sección Puerto Rico del Partido Revolucionario Cubano con sede en Nueva York.

55 Ibidem, pp. 101, 177-8, 501.

56 Ibidem, pp. 6, 28-35.

57 Con esta apreciación, Rivero pretende rectificar la idea generalizada de que España abandonó a Puerto Rico a sus propias fuerzas ocupándose sólo de Cuba. Su tesis es que prevalecía en las autoridades peninsulares la conciencia de que Cuba se bastaba a sí misma $y$, que, de todas formas, ya estaba perdida, por lo que se pensó concentrar la defensa en Puerto Rico y con el propósito de reforzarla se envió a esta isla la Armada de Cervera, p.
}

\section{R. I., $1997, \mathrm{n}^{\circ} 211$}


un plan inmediato contra Puerto Rico que era «un hueso más fácil de roer que Cuba» y serviría de base naval importante para amenazar de flanco las comunicaciones entre España y Cuba y para contrarrestar cualquier intento de la Armada de Cervera y otros buques auxiliares que pudieran armarse en corso. El bombardeo de San Juan y las dificultades de Cervera para abastecerse de carbón, hicieron que su escuadra tuviera que reorientar el rumbo y refugiarse en Santiago de Cuba, desviando de Puerto Rico el foco principal de la gue$\mathrm{rra}^{58}$. A pesar de exponer estos antecedentes, Rivero insiste en que fueron los anexionistas los responsables de traer la guerra a Puerto Rico. Su tesis, reafirmada posteriormente por el propio Todd, prevaleció largo tiempo en la historiografia puertorriqueña. Ya ha sido superada por estudios que demuestran el viejo interés de los Estados Unidos en Puerto Rico 59 .

Otros anexionistas llegaron con las tropas norteamericanas o se unieron a ellas después del desembarco y actuaron de escuchas, facilitándoles el camino y sirviéndoles de intérpretes y enlace. Entre ellos, Rivero destaca a Eduardo Lugo Viña, Antonio Mattei Lluveras y Mateo Fajardo, quienes precedieron las operaciones de la brigada del general Schwan desde Yauco hasta el río Guasio ${ }^{60}$. En el caso de la toma del pueblo de Fajardo, relata con detalles la intervención del Dr. Santiago Veve Calzada. Frente a los anexionistas, Rivero mantiene una cierta distancia; no le son hostiles, ni tampoco los juzga. Más bien los respeta, sobre todo a Lugo Viña, de quien afirma que aunque rebelde y sin hábitos militares, obedeció leyes y costumbres castrenses, no realizó actos reprobables y, como sus hombres, expuso siempre el pecho a las balas españolas ${ }^{61}$. Añadió otros elogios

\footnotetext{
140. Sin embargo, la sensación de abandono, aunque por otros motivos, fue experimentada fuertemente por el propio Rivero la noche del bombardeo de San Juan. [1]. Cf. pp. 96-97.

58 RIVERO, [1], pp. 140, 176-7.

59 Cf. Roberto H. TODD, La invasión americana. Cómo surgió la idea de traer la guerra a Puerto Rico. San Juan de Puerto Rico, Cantero Fernández y Co., Inc., [1939]; María Eugenia Estades Font, La presencia militar de Estados Unidos en Puerto Rico, 18981918. Río Piedras, Ediciones Huracán, 1988; Gervasio Luis GARCíA, «Strangers in Paradise? Puerto Rico en la correspondencia de los cónsules norteamericanos (1869-1900)» en op. cit. Revista del Centro de Investigaciones Históricas, núm. 9, El Caribe entre imperios (Coloquio de Princeton), 1997.

60 Ibidem, pp. 269, 296-7,300, 377-8, 428, 436-7.

${ }^{61}$ Ibidem, p. 428. Lugo Viña organizó una sección montada denominada «Porto Rican Scouts».
}

R. I., $1997, \mathrm{n}^{\circ} 211$ 
reproduciendo opiniones expresadas sobre él por Schwan y por el sargento Karl Stephen, quien lo asemeja al general cubano Máximo Gómez ${ }^{62}$.

En fin, Rivero se muestra convencido de que el tipo de «guerra civilizada»e inteligente que pelearon los norteamericanos les limpió de obstáculos el camino, permitiéndoles un paseo triunfal. Apreciamos antes un revelador párrafo donde Rivero resume las virtudes más sobresalientes. Frente a éstas, contrastan las torpezas del mando español y las imposiciones antipáticas que mantuvo hasta el último momento, como fue la de ordenar requisas, «arrebatando a infelices campesinos sus míseros caballos y mulas para remontar las guerrillas y transportar las cargas» con lo que huían a los montes o buscaban amparo en los pueblos invadidos ${ }^{63}$. En cambio, los norteamericanos pagaban por todo lo que tomaban. Sin embargo, Rivero no abunda más sobre los motivos del descontento. Se atiene a los hechos de tiempos de la guerra y silencia las múltiples razones que tenían acumuladas los puertorriqueños, sobre todo los más humildes, para resentir el gobierno español y que salieron a flote cuando surgió la ocasión ${ }^{64}$. Por ejemplo, no alude en absoluto a los «meses del terror» (agosto-noviembre) vividos en 1887, cuando se fundó el Partido Autonomista Puertorriqueño en medio de una fuerte crisis económica y se desató una feroz persecución contra los hijos del país. La región del suroeste, la primera que ocuparon los norteamericanos, fue la más azotada por los compontes y tenía aún en el 98 heridas profundas pendientes de cicatrizar ${ }^{65}$. Rivero da cuenta de la algarabía popular en los pueblos cuando se celebraba el traspaso de poderes, pero sin indagar las causas, despachándolas implícitamente como reacciones del populacho. La caballerosa conducta de las tropas nortea-

62 RIVERo, [1], pp.296-7. La Crónica que nos ocupa ofrece valiosas pistas sobre individuos de ideas anexionistas y personas fichadas por el gobierno español como poco afectas al régimen español y simpatizantes de los norteamericanos.

63 Ibidem, p. 472.

${ }^{64}$ Cf. Gervasio L. García, «Puerto Rico en el 98: comentario sobre el Informe Carroll», en Historia crítica, historia sin coartadas. Río Piedras, Ediciones Huracán, 1985, pp. 119-33.

65 Para conocer la época del componte cf. Antonio S. PEDREIRA, El año terrible del 87. Sus antecedentes y sus consecuencias. San Juan, Biblioteca de Autores Puertorriqueños, 1937; del mismo autor, Un hombre del pueblo. José Celso Barbosa. San Juan de Puerto Rico, s.e., 1937; Lidio CRUZ MonClovA, Historia del año 1887. Río Piedras, Editorial de la Universidad de Puerto Rico, 1958.

R. I., $1997, \mathrm{n}^{\circ} 211$ 
mericanas para evitar agravios a las tropas salientes recibe mayor atención de su parte ${ }^{66}$.

La atención dada a los factores anteriores, sobre los cuales el autor hace girar las razones para el cambio en la actitud de los puertorriqueños y fija el nudo gordiano del problema, no contradice ni desvirtúa otro elemento importante: el de la desproporción existente en los recursos de guerra con que contaban las tropas invasoras y las defensoras. Aunque en un contrapunteo de las fuerzas beligerantes reconoce el desbalance existente, su enfoque vuelve a centrarse en el liderato. En lo que se refiere a estrategias ejerce un sentido menos condescendiente con los pasos en falso dados por los norteamericanos.

\title{
CONTRAPUNTEO DE LAS FUERZAS BELIGERANTES
}

\author{
«... este es un libro escrito por un hombre que no tiene miedo \\ a la verdad.»
}

Desde el primer momento, Rivero establece las desigualdades entre las fuerzas contendientes, reflejo a su vez de los imperios que defendían. Uno, el español, estaba en plena decadencia, debilitado por siglos de torpe coloniaje, anquilosado en actitudes trasnochadas y en recursos escasos y añejos. El otro, el norteamericano, era joven, impetuoso, arriesgado, moderno y rico. Aun cuando Rivero expone alternativas tácticas que hubieran podido alterar el resultado de algunos de los encuentros habidos en la campaña, en el fondo sabe que el resultado final hubiese sido el mismo. Cuando la guerra llegó a Puerto Rico ya la suerte estaba echada ${ }^{67}$.

Nuestro autor parte de una reflexión acerca de la mentalidad ante la guerra de unos y otros. Sostiene que los españoles tenían cierta confusión respecto a las finalidades de una guerra. Para ellos, los conceptos de victoria y derrota iban unidos; la suprema aspiración

\footnotetext{
66 RIVERO, [1], pp. 217-8, 220-1.

${ }^{67}$ Esa fue al parecer la actitud asumida por el alto mando peninsular en San Juan a juzgar por las decisiones que tomó. frente al Estado Mayor, contrapone la figura del general Ortega, quien estuvo dispuesto a morir en la defensa de la plaza. «No digo, porque no es posible decirlo, que San Juan no se hubiese rendido; seguramente sí. Pero al entrar en su recinto, Davis y sus compañeros, sólo hubiesen pisado cadáveres y ruinas.» p. 463.
} 
era «morir con honra», fuera en la victoria o en la derrota. Más que al triunfo, aspiraban a mantener el honor en alto. A las fuerzas de mar y tierra se les pedía «honor y coraje». Creían que el patriotismo era suficiente para enfrentar al enemigo y el recuerdo de viejas hazañas les llenó de sobreconfianza. De ahí que, mientras los norteamericanos compraban buques, los españoles pensaban que éstos serían buenas presas para los corsarios catalanes y mallorquines. Estas ideas, promovidas desde los amplios salones del Ministerio de Marina y exaltadas en campañas periodísticas, crearon un ambiente de falso optimismo que permeó los primeros momentos de la guerra en la metrópoli y en sus colonias. A los cruceros de combate se les llamó acorazados, cuando la mayor parte de ellos carecían de armamento adecuado, tenían sus máquinas casi inútiles y sus cascos corroídos, las tripulaciones carecían de instrucción y muchos de los que tenían cañones a cargo nunca habían disparado uno. Entre todas las falsedades promulgadas sólo resultó verdadero el valor, el arrojo y el heroísmo de los marinos españoles ${ }^{68}$. Estas virtudes, como la del honor, por muy nobles que fueran, probaron ser insuficientes para enfrentar a un formidable enemigo.

Rivero está consciente de esa situación enajenada. Responsabiliza en primer lugar al contraalmirante Segismundo Bermejo, ministro de Marina hasta la segunda quincena de mayo en que fue sustituido por el capitán de navío de primera clase Ramón Aunón. Según Rivero, Bermejo era un hombre culto y patriota, temeroso del qué dirán, muy atento a los devenires políticos y alejado de la realidad marinera por su larga permanencia en cargos de oficina. Su juicio es draconiano. «Realmente, el Alto Mando de la Armada española no fue durante toda la guerra sino un gallardo acorazado que había echado anclas, todas las de a bordo, en los amplios salones del Ministerio de Marina.» ${ }^{69}$

Frente a Bermejo, contrapone primero la figura del almirante Pascual Cervera, marino ilustre, práctico, que anticipó lo que ocurriría, pues conocía el pobre estado de la Armada española y no menospreciaba al enemigo. Aunque protestó de que se le empujara hacia un destino insalvable, fue desoído y, «entonces, puesta su con-

68 Rivero, [1], pp. 117-20.

${ }^{69}$ Ibidem, p. 118.

R. I., $1997, \mathrm{n}^{\circ} 211$ 
fianza en Dios, sale en busca de la muerte» ${ }^{70}$. Rivero sintió una gran admiración por Cervera y dedicó los apéndices 8 al 11 del libro a narrar cómo había ocurrido la destrucción de su Armada en Santiago de Cuba y los acontecimientos que le siguieron. En ellos vuelve a contrastar las actitudes norteamericanas con las españolas. Mientras los oficiales del Norte honraron al marino vencido como un héroe, recibiéndole caballerosamente durante su cautiverio y dispensándole afectos, reconocimientos y distinciones, en España, el Consejo Supremo de Guerra y Marina, incoó un proceso acusándole a él y a los demás comandantes de los cruceros destruidos por el desastre de Santiago. La prensa ayudó a crear una opinión pública vejatoria contra el almirante y sus oficiales. En cambio periódicos y revistas norteamericanos le colmaban de elogios. Los oprobios de que fue objeto en su patria trataron de enmendarse poco después y, en 1902, el gobierno le nombró jefe del Estado Mayor de la Armada, cargo recién creado. No obstante, los honores recibidos en el ocaso de su vida (murió en 1909) no podían borrar tan fácilmente las injusticias y los sinsabores padecidos a su regreso a una España vencida. En última instancia, la imagen que reconstruye Rivero de Cervera es la del héroe potencial que terminó convertido en villano vilipendiado por la pérdida de los últimos retazos del imperio americano; acaso una de las principales víctimas de la guerra ${ }^{71}$.

El abogado John Davis Long era en Washington la contraparte de Bermejo. Rivero lo describe como un hombre «excepcional, un genio», cuya sabia dirección dio a la marina norteamericana la mayor parte de sus triunfos. Anticipó la guerra, guió acertadamente los preparativos, movió los resortes diplomáticos, reforzó las fuerzas navales sin escatimar en los desembolsos necesarios, y se mantuvo siempre bien enterado de la situación de la marina española y de todos sus movimientos. Según Rivero, si Cervera pudo llegar con su Armada hasta Santiago burlando la vigilancia norteamericana, se debió a que Sampson, desobedeciendo o interpretando a capricho las órdenes recibidas desde Washington, bombardeó a San Juan, de lo que se enteró el almirante español en Martinica, escurriéndose por el sur ${ }^{72}$.

\footnotetext{
70 RIVERO, [1], p. 118.

71 Ibidem, p. 118-23; 594-607.

72 Ibidem, p. 121-3.
} 
El planteamiento de Rivero es claro. Las máximas autoridades peninsulares crearon falsas expectativas de lo que podría esperarse de una guerra con los Estados Unidos y una imagen ficticia sobre sus propias fuerzas navales, que, junto a los desaciertos del mando, llevó a España a una derrota anunciada. Esta tesis es sostenida hoy, mucho más elaborada y sustentada desde luego, por varios intelectuales españoles ${ }^{73}$. Si Rivero no tenía muy clara esta idea cuando escribió su diario, ya la había definido cuando redactó su historia dos décadas más tarde. Lo que Rivero no indagó fue por qué actuó de ese modo el gobierno español, limitándose a señalar la desidia e incompetencia de algunos jefes. Ya advertí antes que en su historia, los actores determinan la acción. Es una crónica de figuras y contrafiguras.

El perfil que deja Rivero de los líderes principales de la campaña de Puerto Rico guarda la misma desproporción que hemos observado respecto a las incidencias militares. El capitán general/gobernador, Manuel Macías y Casado, se presenta como un hombre bueno, afable y culto, pero débil de carácter, más interesado en sus funciones de jefe político que en las de estratega al mando de una plaza en guerra. Dejó las cuestiones militares en manos del jefe de su Estado Mayor, de quien fue «prisionero voluntario» ${ }^{74}$. El «villano» principal —el antihéroe-, fue el coronel Juan Camó, para quien Rivero reserva los juicios más duros.

\begin{abstract}
...hombre viejo y que decía conocer al país, al que jamás quiso bien, no desperdiciando ocasión de tachar a los portorriqueños de traidores, desleales y pusilánimes. De aquí tomaron origen las desconfianzas y temores que hicieron rechazar numerosas ofertas espontáneas de millares de hombres que pedían armas para defender la causa de la soberanía nacional.

... hosco, reservado, despótico en grado sumo, no admitía réplicas ni observaciones de persona alguna. Jamás enmendó su criterio. Fue siempre señor y dueño de las fuerzas militares que guarnecían la Isla y hacía y deshacía a su antojo procurando, en todos los casos, contrariar a sus subordinados, y aun a los de su misma o superior categoría.

... Fue una losa de plomo, un martillo pilón, que gravitó y batió, por muchos años, sobre todos los que tuvieron la desgracia de caer dentro de su amplia jurisdicción. Por esto era mal querido en cuarteles y cuar-
\end{abstract}

\footnotetext{
73 Entre ellos Carlos Serrano, Final del imperio. España, 1895-1898. México, Siglo Veintiuno Editores, 1984.

74 RIVERO, [1], pp. 470-1, 479-80, 511.
}

R.I., 1997, n. $^{\circ} 211$ 
tos de banderas, no gozando entre el elemento civil de mejor reputación ni de mayores simpatías; y así, cuando se embarcó para Cádiz después de firmarse el Armisticio, fue el único jefe español a quien nadie acompañara a bordo y no hubo entre las suyas una sola mano amiga que las apretara en despedida, y los periódicos, con sorprendente unanimidad, le dedicaron sueltos y artículo, que eran verdaderas diatribas.

No fue el coronel Camó un cobarde, un traidor ni un torpe; fue solamente un jefe obcecado, retrógrado, miope e incapaz de torcer sus opiniones ni sus juicios. Sus resoluciones, que influyeron en el procesamiento de los coroneles Soto y San Martín, fueron otras dos grandes injusticias, porque aquellos jefes procedieron, siempre, dentro de las instrucciones superiores que tenían recibidas. El suicidio de Francisco Puig, teniente coronel del batallón de Cazadores de la Patria, fue debido, exclusivamente, a la dureza del lenguaje y trato injusto que recibiera aquel jefe del coronel Camó.

Las actuaciones de este jefe, en quien deben recaer todas las responsabilidades de la campaña en Puerto Rico, pueden condensarse en pocas frases: «nada hizo, nada dejó hacer; desconfió de todos, y de todos fue malquisto.» ${ }^{75}$

Del alto mando español en Puerto Rico, Rivero guarda la mejor opinión para el general Ricardo Ortega Diez, segundo cabo de la capitanía general, a quien describe como valeroso, de carácter franco y generoso, aunque a veces impulsivo y rencoroso. Sus consejos y sugerencias fueron desatendidas por el Estado Mayor y pasó la guerra acuartelado en San Cristóbal, desde cuyas baterías más altas y descubiertas dio muestras de valentía durante el bombardeo de San Juan. Con buen humor confió a Rivero, el 25 de julio, antes de conocer la noticia del desembarco por Guánica, que sus deseos eran capturar a un yanqui para verle la cara y un buque enemigo para anclarlo en la bahía y dormir en él la siesta todos los días. Al día, siguiente, al enterarse de la noticia, Rivero comenta que Ortega amaneció «intratable» y sin poder disimular la opinión que le merecía el coronel Camón ${ }^{76}$.

75 RIVERO, [1], pp. 479, 495-7, 570. Llama la atención que ni siquiera aparezca su foto entre las muchas que aparecen de los jefes de ambos bandos.

76 Ibidem, pp. 44, 73, 483-6, 547, 559. Fue Ortega quien, a mediados de febrero de 1898, ordenó el arresto de Rivero en el Morro, injustamente, al decir del cronista. Después, las experiencias compartidas en San Cristóbal durante la guerra promovió el aprecio mutuo y la amistad. p. 1.

R. I., 1997, n. $^{\circ} 211$ 
Ninguno de los jefes norteamericanos ameritó un juicio peyorativo como el de Camó, ni siquiera Sampson, el que más antipático le resulta a Rivero por el ataque ilegal a San Juan. También mereció sus críticas Guy V. Henry por haber ocupado a Lares después de haberse firmado el armisticio ${ }^{77}$. Entre los contrarios, el héroe máximo para Rivero es Miles. Considera que su oportuna intervención en Santiago de Cuba aseguró la rendición de dicha plaza, pero lo que lo cautivó fue su manera de conducir la guerra en Puerto Rico, algo que tratamos anteriormente.

...Yo he sentido, desde hace mucho tiempo, honda admiración y simpatía por este caudillo valiente, noble, sagaz y tan amante de la verdad, que siempre la dijo frente a todas las conveniencias y de las más elevadas personalidades.

Su manera de conducir la guerra en Puerto Rico debe de servir de modelo a los futuros generales ${ }^{78}$.

Mas no todo el paseo fue triunfal para los norteamericanos. Algunas de las compañías también eran bisoñas, estaban aún resentidas por la travesía marítima, carecían de experiencia y disciplina, estuvieron mal alimentadas, al menos durante algunas operaciones, y padecían los rigores de un trópico al que no estaban amañados ${ }^{79}$. Donde más parejas parecieron las cosas en algunos momentos fue en la situación de las tropas. Desde luego, nada de esto supo aprovechar el mando español, que ordenó la retirada de las tropas veteranas y fomentó la desbandada de las fuerzas voluntarias auxiliares.

Con excepción del valor y el coraje demostrado por los soldados y marinos españoles siempre que tuvieron ocasión, el contrapunteo entre las fuerzas combatientes arroja un marcado desbalance a favor de las norteamericanas. Del liderato hacia abajo, todas las comparaciones demostraron la superioridad de los invasores: la marina, las armas, los planes y las estrategias de guerra, la asistencia médica, y la labor de los cuerpos de ingenieros. En ocasiones, la situación describe rasgos patéticos, como cuando consigna en su diario, el 21 y 30 de marzo, que sus artilleros practicaban ejercicios simulados, sin

\footnotetext{
77 RIVERO, [1], pp. 350-1.

$78 \mathrm{Ibidem}$, p. 483. Rivero reconoce entre las «hazañas» militares de Miles, sus triunfos sobre diferentes pueblos indígenas de Norteamérica.

79 Ibidem, pp. 200, 203, 221.
}

R. I., 1997, n. $^{\circ} 211$ 
disparar los cañones porque tenían que guardar las escasas municiones por si se declaraba la guerra ${ }^{80}$.

\section{LAS FISURAS EN LA GUERRA CULTA}

«... la guerra, aun en sus períodos de mayores suavidades, es la sublimación de toda crueldad.»

El deslumbramiento de Rivero por la superioridad castrense de los norteamericanos no anula su sentido crítico. De toda la campaña de Puerto Rico, la acción que con mayor entusiasmo describe, por considerarla la más importante, fue el bombardeo a San Juan, en el que intervino directamente al frente de las baterías defensoras de San Cristóbal. Exalta las maniobras navales de la escuadra del contraalmirante William T. Sampson, «tan precisa, tan elegante y tan serenamente realizada... Parecía un simulacro.» A la vez critica que el $80 \%$ de los proyectiles que disparó hacia la ciudad no funcionaban. Encuentra admirable su descuido, y se pregunta en qué pensaban los artilleros enemigos ${ }^{81}$, sin plantearse si fue una acción deliberada de Sampson que atacaba sin aviso previo a una población civil en lo que fue quizás una operación de advertencia con la intención de amedrentar. Fustigó a Sampson por su ataque sorpresivo, que consideró un «acto de guerra innecesario, cruel y abusivo», mas también por su indisciplina militar ${ }^{82}$.

Terminada la guerra, Sampson explicó su proceder en el Century Magazine. Afirmó haber atacado bajo la presunción de encontrar en el puerto de San Juan a la escuadra de Cervera y sostuvo que ni una sola vez sus cañones fueron dirigidos hacia la ciudad, por lo que cualquier daño sufrido por ésta fue incidental. Rivero lo refuta. Aduce que él debió saber, por los informes que recibía de Long y de otros confidentes, que la Armada de Cervera se encontraba entonces

\footnotetext{
80 RiVERO, [1], p. 534.

81 Ibidem, pp. 97, 550-1.

82 Ibidem, p. 91. Hay leyes humanas que no necesitan para ser cumplidas estar consignadas en ningún código; son leyes de humanidad, de amor y respeto hacia las mujeres, hacia los niños, hacia los ancianos, y que se extienden a todos los no combatientes.
} 
frente a Martinica ${ }^{83}$. Además, pudo comprobar que la Armada no estaba en San Juan mediante el examen del puerto que hizo la lancha del Wompatuck. A pesar de ello, atacó, en horas de la madrugada, sin autorización de sus superiores. Rivero está convencido de que Sampson quiso emular la hazaña del almirante Dewey al forzar la entrada al puerto de Manila porque había sido informado de que la plaza de San Juan, como la filipina, estaba pobremente artillada. Para Rivero, su fin era capturar la ciudad murada y no el de practicar un mero reconocimiento, aunque confiesa que no sabe por qué Sampson optó por no forzar el puerto cuando pudo haberlo hecho, acción que le hubiera reivindicado como estratega de guerra. Rivero concluye implícitamente que el bombardeo de San Juan, practicado a mansalva, «violando todas las reglas del derecho de gentes y los sentimientos de la humanidad», fue la mancha de las fuerzas norteamericanas durante la guerra. En cambio, sostiene que «fue una indiscutible victoria de las armas españolas; la única... durante la guerra hispanoamericana». Puesto que Sampson vino con un objetivo y no lo realizó, fue derrotado según el tecnicismo militar ${ }^{84}$. Nuestro autor no puede sustraerse al orgullo castrense de reclamar su victoria.

Respecto al resto de la campaña de Puerto Rico, Rivero reparte alabanzas y censuras en lo que toca a cuestiones tácticas. Los mayores elogios van hacia los invasores, si bien no están exentos de juicios desfavorables. Por ejemplo, resalta la decisión de Miles de cambiar el plan inicial de desembarcar por Fajardo, que ya conocían las autoridades insulares, y hacerlo por Guánica, pero considera equivocada la división de las tropas desembarcadas en cuatro débiles columnas que siguieron rutas independientes, sin enlace entre ellas, transitando difíciles parajes en pleno verano y bajo frecuentes lluvias que convertían caminos y campamentos en húmedos lodazales. Considera que éstas pudieron ser destruidas por fuerzas españolas, impidiéndolo la inacción del Estado Mayor. Argumenta que tal plan sólo podría justificarse si ellos sabían que el protocolo de paz estaba cerca $^{85}$.

\footnotetext{
${ }^{83}$ Rivero identifica como informantes al ingeniero inglés Scott, a Andrés Crosas, José Julio Henna, y al cónsul Hanna.

${ }^{84}$ RIVERO, [1], pp. 96-97, 101-6, 142.

85 Ibidem, pp. 457-60.
} 
Vimos antes las impugnaciones que hace Rivero a las decisiones del mando militar en Puerto Rico. Parecen un catálogo de desconciertos, desaciertos e injusticias. Desde ese punto de partida es fácil imaginar el resto. E' desembarco por Guánica les pilló por sorpresa y como no tenían planes alternos y no estuvieron dispuestos a atender sugerencias, imperó el caos; se dieron órdenes y contraórdenes sin un propósito definido y coherente. Cuando se recobró la calma y hubo mayor claridad de pensamiento para disponer combates, llegaron los rumores de que el armisticio estaba próximo e imperó la inacción ${ }^{86}$. Persistió la voluntad de Camó de no enviar tropas a la región suroeste y, en cambio, iniciar la retirada de éstas para una supuesta concentración de tropas en Arecibo que nunca se llevó a efecto. Las tropas invasoras pudieron recorrer el territorio con un mínimo de resistencia.

Al concluir la guerra el sentimiento general de la población, aún en medio de la algazara exteriorizada en el momento, debió ser de confusión e incertidumbre. El telón español había caído y se dibujaba un nuevo horizonte tan lleno de esperanzas como de incógnitas e imponderables. Muchas personas debieron compartir la sensación de desamparo y abandono que experimentó Rivero la noche del 12 de mayo mientras cavilaba sobre el bombardeo de San Juan.

Yo afirmo, por mi honor, que aquel día hice cuanto pude para hundir uno o muchos de los cruceros de Sampson; a mitad del combate, y ya dueño de mis nervios, comprendí lo mísero de nuestra situación, lo pobre de nuestro armamento, la inexperiencia de nuestros artilleros, que jamás hasta entonces, habían escuchado el disparo de un cañón; entonces maldije de aquellos hombres del Ministerio de la Guerra de Madrid, que pudiendo y debiendo haber hecho tan grandes cosas, nos dejaron indefensos y a merced del enemigo. 8787

\section{LA VIDA CIVIL DURANTE LA GUERRA}

«Los americanos nos bloquean, pero nos compran el azúcar; ¡menos mal!»

\footnotetext{
86 RIVERO, [1], pp. 462-3

87 Ibidem, pp.96-7.
} 
La pasión con la que Rivero narra las incidencias militares se complementa con el humor y la ironía con que cuenta ocurrencias vividas en la ciudades y en los pueblos ocupados, sobre todo en la urbe capital por permanecer en ella, con breves excepciones, durante todo el tiempo que duraron las hostilidades. Tanto así, que dedica el último capítulo a misceláneas, en las que mezcla anécdotas de índole variada. En realidad, estas reseñas se encuentran dispersas a lo largo de todo el libro y, desde luego, en el diario.

Expuse antes que Rivero es un implacable observador de la conducta humana. Entre las actitudes que más llamaron su atención estuvo la de los embriscados, como se llamó a las personas que huían de San Juan, por la bahía, en embarcaciones que los llevaban del otro lado hasta Cataño, o por carretera hacia Santurce, Río Piedras, Carolina y otros pueblos del interior. Los que pudieron llegaron hasta Saint Thomas ${ }^{88}$. Trata el tema de diferentes maneras. A veces siente dolor y comprensión al observar las penosas caravanas, como ocurrió durante el bombardeo cuando muchos huyeron «en abigarrado tropel, como un rebaño en desbandada ${ }^{89}$. También está presente la sensación de soledad y vacío en que van quedando los defensores de la ciudad desierta ${ }^{90}$. En otras ocasiones trata a los fugitivos con ironía: «muchos hombres, tenidos por valerosos, buscaban alivio a sus dolencias reumáticas en las termas de Coamo, o agobiados por los calores de julio y agosto colgaban sus hamacas en las frondas de Toa Alta, Guaraguao y Guaynabo, y otros llegaron más allá de nuestras playas.... ${ }^{91}$ Pero quizás, la nota predominante con la que se refirió a ellos fue el humor irónico, a veces propio, a veces de origen popular y otras veces reproduciendo notas aparecidas en la prensa, como es la que sigue.

«Un amigo nuestro nos ha pedido precio por la impresión de dos mil folletos que piensa publicar para venderlos a 50 centavos ejemplar, titulado, Los embriscados. El aludido libro se dividirá en cuatro capítulos. El primero dedicado a los embriscados pudorosos, que se marchan a escondidas por las noches; el segundo a los intermitentes, que vienen por las mañanas y se ausentan por las tardes; el tercero a los

\footnotetext{
88 RIVERO, [1], pp 90, 556.

89 Ibidem, pp. 90-91, 558.

90 Ibidem, p. 543, 548, 560.

91 Ibidem, p. 114.
}

R. I., 1997, n. ${ }^{\circ} 211$ 
eventuales, que desaparecen en cuanto circulan rumores de peligro, y el cuarto a los fijos, que no volverán sino después de firmada la paz. Será un libro curioso, porque tendrá los nombres, edades, profesiones, cargos que desempeñaban, fechas de salida, sueldos que gozan y sitios de residencia.

Se dice que no falta algún habitante temporero de las sierras del Guaraguao que encuentre deliciosa la vida de las montañas y que ya coma con gusto el arroz con perico, funche, majarete, mundo nuevo y hasta los caimitos, icacos y jobos, ponderando la riqueza de manjares y frutos montaraces que desconocía hace tres meses. No hay nada tan eficaz como los anuncios de bombardeos, para desarrollar el gusto, por estudios prácticos, de las costumbres campesinas.» ${ }^{92}$

Las filas de los embriscados, debieron incluir representantes de las diferentes esferas sociales y así lo sugieren las anotaciones del diario, pero Rivero denuncia principalmente a los comerciantes y funcionarios que marchaban llevando sus pertenencias: muebles, aparadores y hasta mostradores ${ }^{93}$. El humor popular llamó «acorazados y destróyers» a los que se ausentaban rápidamente cuando se avistaban buques sospechosos, porque, como las embarcaciones, siempre tenían las calderas encendidas ${ }^{94}$. Y al brazo de mar entre San Juan y Cataño le llamaron las «Termópilas», a lo que Rivero comenta con humor que todavía (escribe el 3 de julio) no se había aparecido «ningún Leónidas ni mucho menos sus trescientos espartanos» ${ }^{95}$. El regreso comienza a registrarse desde el 7 de agosto cuando empezó a concentrarse en San Juan la Guardia Civil y muchos embriscados temieron que el campo quedara en manos de las partidas sediciosas. Los rumores de que la paz estaba cerca hicieron el resto. A principios de septiembre la gente había regresado a San Juan ${ }^{96}$.

Otro asunto que Rivero aborda con insistencia y propósito rectificador es el referente al bloqueo de San Juan por la Armada norteamericana, tema recurrente en la historiografía posterior que trata la situación económica del país en los años finales del siglo XIX. Rivero sostiene que la isla nunca estuvo bloqueada con efectividad.

\footnotetext{
92 Rivero, [1], pp. 524-5 . Escrito por el periodista Juan B. LÓPEZ, apareció en $L a$ Correspondencia. Énfasis en el original.

93 Ibidem, pp. 552, 557.

94 Ibidem, pp. 552, 556.

95 Ibidem, p. 554.

${ }^{96}$ Ibidem, pp. 563-4, 568.
} 
Sólo San Juan permanecía bajo la vigilancia de buques enemigos y esto con largas y frecuentes interrupciones. Afirma que por lo regular sólo había un vapor patrullando la entrada a la bahía y que en todos los puertos del litoral y a menudo en el de San Juan entraban cada semana barcos de vapor abarrotados de subsistencias. Niega que hubiera temores de hambre e incluso atestigua que dos meses después del armisticio se subastaron cantidades crecidísimas de provisiones sobrantes en la Administración militar. Asegura que si no llegaron más barcos con aparatos militares se debió a la apatía de las autoridades peninsulares, pues no pidieron a tiempo lo que el ejército necesitaba para batirse ventajosamente con los invasores ${ }^{97}$. En el diario figuran con frecuencia noticias sobre la llegada de embarcaciones con provisiones y carbón, incluso algunas de cabotaje ${ }^{98}$. Los puertos de Ponce y Mayagüez se mantuvieron activos libremente y el ministro de Ultramar concedió entrada franca en todos los puertos de la Península, Canarias y Baleares a los productos de Puerto Rico, a excepción del tabaco. Perspicaz, nuestro autor deja escapar su sentir en las páginas del diario: «Es bien triste que el deseado cabotaje, por el cual se ha luchado tantos años, lo vengamos a obtener ahora, gracias al cañón del enemigo.» ${ }^{99}$ Aunque no lo dice, algo parecido pudo haber exclamado respecto al gobierno autonómico.

Ni siquiera se suspendió durante la guerra el comercio con los Estados Unidos. El 1 de junio apunta en su diario que el vapor inglés Darlington cargó en Mayagüez, para Nueva York, 1.161 sacos de azúcar $^{100}$. El estado de las importaciones/exportaciones con los Estados Unidos publicada por La Gaceta el 26 de mayo, señala un balance mercantil desfavorable para Puerto Rico. Las exportaciones sumaban 2.644.739,97 pesos mientras que las importaciones se elevaban a 4.117.984,90 pesos $^{101}$. Y las aduanas de julio recaudaron $73.492,11$ pesos. «iVaya un bloqueo!», comenta Rivero ${ }^{102}$. No conozco ningún estudio científico sobre el bloqueo que me permita refutarlo.

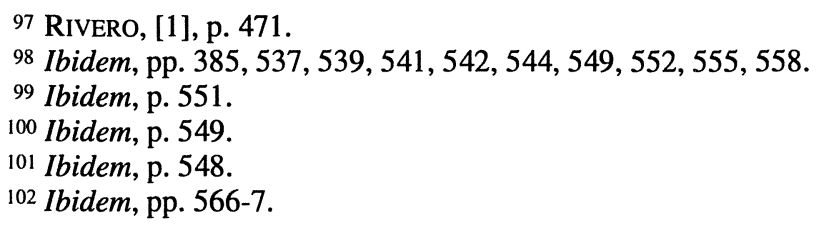

R. I., $1997, \mathrm{n}^{\circ} 211$ 
Mas una cosa es que no faltaran provisiones en el país y otra que éstas estuvieran accesibles a la población. La crisis económica de la década, agravada por el estado de guerra, provocó hambre y desestabilidad social. Rivero anota en el diario las noticias que se reciben sobre robos y matanzas de ganado por parte de campesinos hambrientos. En Sabana Grande, recorren la población pidiendo auxilio; en San Juan aumentan los robos ${ }^{103}$. La expresión más conspicua del deterioro y el desasosiego social fueron las partidas sediciosas, que Rivero condena rotundamente. Las describe como «partidas de ladrones y de incendiarios», actos de vergonzoso bandidaje» $\mathrm{y}$ «turbas desenfrenadas», comparándolas con troncos desprendidos y demás desperdicios que flotan cuando los ríos desbordan sus cauces. Las diferencia asimismo de las partidas auxiliares que se crearon por ideales políticos para apoyar a uno $\mathrm{u}$ otro bando ${ }^{104}$. Las partidas han sido objeto de un excelente estudio realizado por Fernando Picó que las pone en perspectiva dentro de las teorías del bandidaje social que surge en momentos de fuertes crisis económicas como la que atravesaba Puerto Rico a fines de siglo ${ }^{105}$.

Cuando concluyó la guerra, el tesoro de Puerto Rico estaba en bancarrota. Sólo quedaba en arcas una moneda de oro ecuatoriana, de escaso valor ${ }^{106}$. Antes de proceder a la evacuación, las autoridades peninsulares dispusieron de las propiedades muebles gubernamentales. Subastaron el material existente en todas las dependencias militares y civiles: víveres, mobiliario, maquinaria, efectos de construcción y animales. Alega Rivero que el dinero obtenido entró en las cajas respectivas y no haber tenido noticias de filtraciones o irregularidades. No deja de resultar irónico, y así lo constata Rivero, que mientras las tropas defensoras pasaron hambre por falta de vituallas, en San Juan los almacenes estaban bien abastecidos con provisiones que les pudieron haber enviado sin mayores contratiempos. En cambio, muchos de esos alimentos terminaron dañados por efectos del clima «u otras razones desconocidas» ${ }^{107}$. Se vendieron fusiles Remington, cartuchos y piezas sueltas de dicho armamento,

${ }^{103}$ RiVERO, [1], pp. 548, 549, 550, 555.

104 Ibidem, pp. 395, 421-426, 428. 565, 570-571.

105 Ibidem, Fernando PiCo, 1898: la guerra después de la guerra. Río Piedras, Ediciones Huracán, 1987.

106 Ibidem, p. 417. Su valor era de $\$ 3,80$.

${ }^{107}$ Ibidem, pp. 385, 441. 
al cónsul de Santo Domingo en San Juan y los bienes que no se vendieron o enviaron a España se donaron al Asilo de Beneficencia. Incluso Macías donó un solar en Puerta de Tierra al Asilo de Ancianos Desamparados, donde se construyó el edificio que todavia hoy los acoge ${ }^{108}$. Puesto que la plaza de San Juan no fue tomada por acción de guerra sino cedida por tratado, la artillería de gran calibre de las fortificaciones también se desmontó y envió a la Península ${ }^{109}$. Se traspasaron al gobiemo norteamericano todos los inmuebles: los edificios públicos y sus terrenos, las fortificaciones, los arsenales, depósitos, muelles y edificios adjuntos y las obras públicas como carreteras, puentes y faros. También se declararon propiedad de los Estados Unidos los papeles y documentos públicos, incluidos los de interés histórico ${ }^{110}$.

\section{VIGENCIA DE LA CRÓNICA}

$$
\text { mia.» }
$$

«Volví a San Juan; ellos regresaban a su patria y yo a la

Para los puertorriqueños, la guerra del 98 es todavía un asunto vivo, estrechamente vinculado a los debates referentes a la solución del estatus político. Bastan para recordarlo palabras como las vertidas en días recientes por el ex-gobernador Luis A. Ferré, en las que afirmaba que en Puerto Rico no había ocurrido una invasión sino un desembarco porque a los norteamericanos se les recibió con los brazos abiertos ${ }^{111}$. La interpretación del máximo líder anexionista del país revela la vitalidad de ese argumento, que fue compartido por la historiografía estadolibrista de las generaciones del 40 al 60. Durante mucho tiempo, sobre todo en los textos escolares, empleó la

\footnotetext{
108 RIVERO, [1], pp. 571 y 480.

109 Ibidem, El derecho a remover el armamento emplazado en las baterías dio lugar a discrepancias entre Ortega y Brooke. La decisión final, que respaldó la posición asumida por Ortega, fue sancionada en el tratado de París y se llevó a cabo en 1904. La comisión española que vino a cumplir tal misión trabajó entre febrero y agosto de 1904 y en los trabajos y atenciones relacionadas se gastaron ca. 40.000 duros. pp.390-3, n. 1 .

110 Ibidem, pp. 390-2, Apéndice núm. 24, pp. 654-9.

111 Ponencia presentada ante la Comisión de Recursos de la Cámara de Representantes del Congreso norteamericano durante las vistas en las que se discute el Proyecto Young sobre el futuro estatus político de Puerto Rico, 19 de marzo de 1997.
} 
frase «cambio de soberanía» con preferencia sobre «la invasión» para restar peso a la imposición militar que nos arrancó de un zarpazo del regazo político español y nos puso en manos de una nueva potencia a la que ya estábamos unidos por fuertes vínculos económicos. Es obvio que mientras permanezca sin solución definitiva el problema de la naturaleza de las relaciones entre la isla y la metrópoli norteña, se mantendrá encandilada la polémica sobre los orígenes de esa dominación y «los justos títulos» para ejercerla.

La Crónica fue uno de dos libros sobre la guerra del 98 publicados en Puerto Rico en $1922^{112}$, pero es el que mayor divulgación ha tenido porque, entre otras cosas, al ser escrito por un criollo participante de los hechos, adquirió el valor de fuente proveedora de datos para historiadores y otros estudiosos del fin de siglo. En particular, la literatura se nutrió de pasajes y descripciones de Rivero para alimentar y reinventar el imaginario de la guerra. Novelas cortas como La llegada, de José Luis González, y La muerte anduvo por el Guasio, de Luis Hernández Aquino, tienen una clara filiación con los relatos de nuestro cronista ${ }^{113}$.

Esta memoria de una guerra que cambió de golpe el destino de Puerto Rico es útil por la información de primera mano que deja sobre los acontecimientos que enmarcaron la campaña, pero también porque ayuda a entender mejor el clima bajo el cual se desarrollaron los hechos. Además adquiere gran actualidad al incitar a un replanteamiento de las circunstancias insulares en el ocaso del régimen español y a una comprensión más abierta de las motivaciones tras el recibimiento que se dio a los invasores. Sobre todo en lo que atañe al papel que jugaron las autoridades peninsulares que regían sobre el gobierno autonómico apenas inaugurado. En este sentido, el libro se incorpora a otros textos de la historiografía actual que explican los porqués de la conducta de los puertorriqueños ante los norteamericanos ${ }^{114}$.

\footnotetext{
112 El otro fue el de Juan B. Soto, Causas y consecuencias. Antecedentes diplomáticos y efectos de la guerra hispanoamericana. San Juan, «La Correspondencia de Puerto Rico», 1922. Es un libro de naturaleza y enfoque completamente diferentes al de Rivero.

113 José Luis GonZÁlez, La llegada (Crónica con «ficción»). Río Piedras, Ediciones Huracán, 1980, Luis Hernández Aquino, La muerte anduvo por el Guasio. Río Piedras. Editorial de la Universidad de Puerto Rico, 1976. La primera edición es de 1960.

114 María Dolores LUQUE DE SÁNCHEZ, La ocupación norteamericana y la Ley Foraker (La opinión pública puertorriqueña) 1898-1904. Río Piedras, Editorial de la Universidad de Puerto Rico, 1980; García [64]; PICO [105].
} 
Rivero identifica al alto mando militar de la colonia como el agente principal que provocó un cambio en los ánimos combativos expresados por los isleños antes de la invasión. A la vez, está muy consciente de que no fue la razón única y de que nada de lo que se hubiera hecho habría podido cambiar, a la larga, los resultados del conflicto. Las décadas transcurridas entre el diario y la Crónica dilataron su perspectiva. Por eso concluye:

No fue arrojada de América la nación descubridora por causas de afrenta. Fue ley fatal e ineludible.

Llegó el instante en que la simiente, hasta entonces dormida, estalló y sus brotes taladraron la tierra, buscando, en el sol y en los gases de la atmósfera, calor y alimento, que los convirtiera en árboles robustos y fructíferos.

No se plegó aquella bandera de sangre con reflejos de oro -más sangre que oro fue su divisa-; es que ya dejó de ser el guión que llevaba a los guerreros al combate, para convertirse en el manto de amor con que la madre cubre a sus hijos.»115

En otras palabras, no fue sólo la superioridad de los armamentos, ni la voluntad de no combatir de las autoridades peninsulares ante una guerra que de antemano sabían perdida, lo que llevó al desenlace conocido. Todo eso contribuyó, pero fue, en última instancia, la disposición del propio país, cansado ya de los desmanes y las actitudes opresivas de una España que poco le ofrecía para extender la participación política de los hijos del país, fomentar el desarrollo económico y mejorar las condiciones de vida de la inmensa mayoría de los habitantes, la que facilitó el triunfo a los norteamericanos, viejos socios en negocios mercantiles y portaestandartes de la imagen de la democracia y la modernidad. Las arbitrariedades e imposiciones de las autoridades peninsulares durante el proceso mismo de la guerra, confirmaron lo que la población ya sabía: que de continuar bajo España pocos cambios podrían esperarse. A fin de cuentas, el país actuó de conformidad con el papel de espectador subordinado que España le había asignado y le exigía, aún en contra de las luchas incesantes de los criollos para participar en la toma de las decisiones que los afectaban en la esfera local. La llegada de la autonomía fue

${ }^{115}$ RIVERO, [1], p. 528.

R. I., 1997, $\mathrm{n}^{\circ} 211$ 
tardía, forzada y poco segura, como lo demostraban los debates que se sostuvieron en Cortes después de comenzada la guerra.

A lo largo de su Crónica, Rivero omite comentarios políticos. El gabinete autonomista pasa casi desapercibido, como si se tratara de un fantasma que flota en el ambiente sin que se le tome en cuenta. Lo menciona en relación con alguna arenga, cuando sufre un cambio interno y, al final, cuando asiste a la entrega de la plaza, mas es ocioso buscar entre las líneas de este texto las posiciones que adoptó el cuerpo frente a las vicisitudes de la guerra. Hasta la foto que aparece de sus miembros es reducida, como si reflejara la función mínima que pudo ejercer en los acontecimientos ${ }^{116}$. La estampa sugerida es la de un cuerpo subordinado que estuvo marginado de las decisiones que tomaron las autoridades militares. Una vez más, por última ocasión durante el régimen español, los líderes locales tuvieron que acatar el rol de observadores impotentes en un conflicto que les concernía directamente. Mas tampoco puede descartarse que Rivero, miembro de un partido adversario de los autonomistas, prefiriera no incluir comentarios que pudieran darle al libro un cariz político que se propuso evitar. También silencia las actitudes asumidas por los diferentes partidos políticos, salvo para mencionar que en los momentos previos todos manifestaron su lealtad a España y la disposición a defenderla. El autor evita a propósito entrar en las polémicas y rencillas que existían entonces y continuaron después bajo el régimen norteamericano.

Rivero, criollo militar y militante en el Partido Conservador Incondicional Español, que empieza la guerra al mando de una de las principales fortalezas defensivas de la plaza murada, termina por aceptar que a España le había llegado su hora y no sólo por ley de las armas. Creo que la guerra y la forma como ésta se condujo en Puerto Rico provocaron un cambio importante en su persona y en su pensamiento político. Sin dejar de sentir a España, reconoce que Puerto Rico aprovechó la coyuntura para dar un nuevo rumbo a su destino y él optó por compartir ese sino, muy incierto aún en 1898. El estado de la investigación sobre Rivero no me permite arriesgar comentarios sobre su trayectoria política en las dos primeras décadas del siglo XX, pero debo destacar que mientras otros militares criollos escogieron trasladarse a España, nuestro autor acató los riesgos

116 RIVERo, [1], p. 39. 
del porvenir de su país. Tampoco aceptó servir en el ejército norteamericano. Las palabras que encabezan esta sección recogen su voluntad al poner distancia entre su patria y la de los españoles que regresaban a la Península ${ }^{117}$. Para Rivero, la provincia se convirtió en nación.

The positioning of the Porto Rican people vis-a-vis the 98 events is analyzed through the study of the War Diary that Angel Rivero Méndez began to write on that same year. This work highlights the fact that the Porto Ricans's dispositions paved the way to the North Americans' triumph. This was a consequence of the colonial past which ended up in the population's weariness vis a vis Spain's end-Century policy, which did not help to promote the development and improvement of the country. The article also analyzes the feelings of confusion and uncertainty experimented by the population at the end of the war.

117 RIVERO, [1], pp. 420, 564-5. En su «noche triste», la del 14 de agosto, Rivero anotó en su diario: «Estoy triste. Me parece como si algún ser muy querido hubiese muerto; y sin embargo, muchos oficiales de la guarnición no hacen nada para ocultar su alegría. "Por fin ha terminado la guerra -dicen- y nos marchamos a nuestras casas; nada nos importa Puerto Rico, y en lo sucesivo ya no soñaremos más con el vómito y otras enfermedades tropicales".» Contrasta esta actitud con la de sus artilleros, tristes y pesarosos por no haberse batido con los invasores.

R. I., $1997, \mathrm{n}^{\circ} 211$ 